The University of San Francisco

USF Scholarship: a digital repository @ Gleeson Library |

Geschke Center

Economics

College of Arts and Sciences

2007

\title{
Credit Information Systems in Less Developed Countries: A Test with Microfinance in Guatemala
}

Jill Luoto

Craig McIntosh

Bruce Wydick

University of San Francisco, wydick@lucas.usfca.edu

Follow this and additional works at: http://repository.usfca.edu/econ

Part of the Economics Commons

\section{Recommended Citation}

Jill Luoto, Craig McIntosh, Bruce Wydick. Credit Information Systems in Less Developed Countries: A Test with Microfinance in Guatemala. Economic Development and Cultural Change (January 2007), vol. 55, no. 2, pp. 313-334. DOI: 10.1086/508714

This Article is brought to you for free and open access by the College of Arts and Sciences at USF Scholarship: a digital repository @ Gleeson Library | Geschke Center. It has been accepted for inclusion in Economics by an authorized administrator of USF Scholarship: a digital repository @ Gleeson Library $\mid$ Geschke Center. For more information, please contact repository@usfca.edu. 


\title{
Credit Information Systems in Less Developed Countries: A Test with Microfinance in Guatemala
}

\author{
JILL LUOTO \\ University of California, Berkeley \\ CRAIG MCINTOSH \\ University of California, San Diego \\ BRUCE WYDICK \\ University of San Francisco
}

\section{Introduction}

The microfinance revolution has brought about unprecedented competition in credit markets within many developing countries. Economists usually view competition favorably, but increased competition in microfinance has resulted in a number of unforeseen difficulties. Recent findings report that greater competition among lenders has increased problems of borrower overindebtedness, reduction of loan repayment incentives, and growing arrears for microfinance institutions (MFIs) in competitive environments (Campion 2001; McIntosh and Wydick 2005).

The weakening performance of microfinance in competitive environments is due in part to the absence of information sharing in these markets. Because growing numbers of MFIs increase the level of asymmetric information between lenders, credit information systems (often called credit reporting bureaus or credit bureaus) can play a crucial role toward improving credit market performance and, in turn, credit access for the poor.

The importance of information in credit markets is well established in such seminal papers as Akerlof (1970), Stiglitz and Weiss (1981), and Hoff and

\footnotetext{
We wish to thank Alain de Janvry, Betty Sadoulet, Tomas Rosada, seminar participants at Princeton University, University of California, Berkeley, and University of California, Davis, and participants in the December 2004 BASIS (Broadening Access and Strengthening Input Market Systems) conference at University of California, Berkeley and the 2002 WEAI (Western Economic Association) meetings in Seattle for helpful comments and encouragement. Financial support from the Leo T. McCarthy Foundation, BASIS/USAID, and the Fulbright Institute of International Education Program is gratefully acknowledged.

(c) 2007 by The University of Chicago. All rights reserved. 0013-0079/2007/5502-0002\$10.00
} 
Stiglitz (1998). Credit information systems act as information brokers that increase the transparency of credit markets. However, in many developing countries, credit information systems are still in their infancy, and information sharing among lenders remains weak. As competition in microfinance lending intensifies in these countries, borrower information becomes all the more important. The MFIs are increasingly utilizing the services of credit bureaus to address a fundamental problem of all credit markets, asymmetric information between borrowers and lenders that can lead to problems of adverse selection and moral hazard. Motivated by industry survival amid increasing competition, a wide array of lending institutions in developing countries are becoming increasingly aware of the essential role that credit information systems play toward the creation and maintenance of an efficient financial system.

This article offers a descriptive account of the growth in credit information systems in developing countries and an empirical test of the effects of a newly implemented credit bureau in Guatemala. Section II of the article provides an empirical description of the credit reporting environments found today in various parts of the developing world, offers a review of previous research on credit information systems, and gives a brief history of the development of credit information systems. In Section III, we present the data set and estimation technique used to capture the screening effects of the newly implemented Guatemalan credit bureau. In Section IV, we present our results, which largely confirm the positive role that information sharing can play in improving lending performance. Our estimations indicate that improved screening effects from the system caused the level of portfolio arrears to decline between 1 and 3 percentage points in the 6 months after it was successively implemented in each branch office. We observe even more substantial effects of the system in reducing late monthly payments made by borrowers. A cost-benefit analysis of the credit information system shows that MFI investment in the system generated an estimated internal rate of return to the institution of $96.5 \%$. Moreover, we find that, in a competitive microfinance market, a reduction in the default rate by our point estimate of 1.92 points would lower interest rates in a competitive market by 2.59 percentage points. These positive effects are sensitive, of course, to the impact of the system on reducing default rates. Section $\mathrm{V}$ concludes with policy recommendations that stem from our research.

\section{Credit Information Systems: Existence, Theory, and Evidence}

\section{A. Credit Bureaus in the Developing World}

Throughout the developing world, the growing availability of consumer credit and the heightened competition among microfinance institutions have made the necessity of credit information sharing all the more apparent. However, 
the extent and efficiency of information sharing mechanisms vary greatly among countries and continents. Africa remains the region of the world with the least developed credit information systems, yet the exploding microfinance sectors in many African countries have sparked interest in the feasibility of the creation of credit bureaus to help manage borrower risk under heightened competition. Similarly, Asian economies are witness to recent growth in credit bureau coverage, including increased awareness of the necessity of information sharing among the multiple microfinance lenders in South Asia. For example, in Bangladesh, the "birthplace" of microfinance, increasing competition among large microfinance lenders such as the Grameen Bank, the Bangladesh Rural Advancement Committee (BRAC), and RD-12 has sparked a World Bank-assisted initiative to introduce a specialized credit bureau into the country's microfinance sector. This credit bureau aims to build a national database in order to manage any systemic risk that might be caused by the present uncoordinated competition among MFIs. The goal is that the credit bureau can help to mitigate the rising problems of nonrepayment of microloans and client overlap among the largest MFIs in Bangladesh. ${ }^{1}$

Latin America arguably has the most extensive coverage of credit information systems among developing regions, with credit information sharing recently being extended even into the microfinance sector. A pertinent example is Bolivia. Prior to 1999, Bolivian law forbade the existence of private credit bureaus (Campion 2001), believing that credit data were too sensitive and important a topic to entrust to the private sector. Meanwhile, its public credit registry had refrained from collecting information from its burgeoning microfinance sector while intense competition among MFIs was allowing clients to borrow from multiple institutions and in numerous cases reaching unsustainable levels of debt, leading to skyrocketing default rates in the microfinance sector in the late 1990s. The crisis led the Bolivian government to rewrite its laws to allow for the existence of private credit bureaus, such that credit bureaus now operate in Bolivia with a special focus on microfinance loans.

\section{B. Theoretical Work}

The subject of credit information systems operating in the microfinance sector has been virtually untouched by the academic literature. McIntosh and Wydick (2004, 2005) show that the existence of a credit bureau may improve credit access for the poorest borrowers. Assuming that credit markets are competitive, information sharing lowers lender costs through lower default rates. This implies that, in a zero-profit equilibrium, borrowers with lower levels of initial

${ }^{1}$ See Matin (2001) for a more complete description of this project. 
assets become added to microlender portfolios. Other research is mostly limited to a number of case studies (Abreu 2001; Campion and Valenzuela 2001; Lenaghan 2001).

A large body of work, however, examines the role that information sharing will play in more developed credit markets. Using a pure adverse selection model, Jappelli and Pagano (1993) analyze the factors that lead to endogenous communication among lenders in a credit market. They find that information sharing is more likely to occur when the mobility of households is high, the pool of borrowers is heterogeneous, the credit market is large, and the cost of information exchange is low. Fear of competition can make lenders hesitant to share their client information, yet a credit bureau is a "natural monopoly" with increasing returns to scale; when some lenders begin to share information, it creates an incentive for other lenders to share information as well.

Vercammen (1995) and Padilla and Pagano (2000) argue that limits to the information exchanged among lenders can lead to improved repayment. Vercammen uses a multiperiod model with adverse selection and moral hazard to show that a certain level of adverse selection is required in a credit market in order to give rise to borrower reputation incentives and thus aggregate welfare. He concludes that a system of full information sharing may be less efficient than one designed to preserve some level of asymmetric information, such as limiting the length of borrower data that is maintained.

Padilla and Pagano $(1997,2000)$ focus on the effect of information sharing as a "borrower discipline device" under perfect competition. They conclude that borrowers have greater incentive to perform if lenders only exchange negative information, arguing that sharing positive borrower characteristics can ease the negative impacts of default and mitigate the disciplinary effect of a credit bureau. Jappelli and Pagano (2000) posit that the usefulness of credit bureaus is reduced in developing countries where large informal sectors exist in which enforcement of repayment is difficult. They suggest that granting credit bureau access to informal lenders would increase the credit bureau's usefulness for both formal and informal lenders due to the economies of scale that define the industry. Jappelli and Pagano also argue that better information may lead banks to shift from collateral-based lending policies to more information-based policies.

Margaret Miller's (2003) Credit Reporting Systems and the International Economy provides a comprehensive source for the institutional aspects of credit reporting. Miller's own chapter in the volume uses results from a World Bank internet survey to offer empirical data on the status of credit reporting activities around the world. Miller shows how credit bureaus can provide borrowers with "reputation collateral," frequently viewed as more valuable than physical collateral 
by surveyed lenders. Furthermore, Miller argues that the types of data collected by a credit bureau often provide the best predictors of repayment.

Jappelli and Pagano (2002) provide an initial empirical investigation of the existence and impacts of credit bureaus in various economies around the world. They find that the presence of credit information systems is associated with broader credit markets and lower credit risk. Nevertheless, rigorous evaluation methods on the effect of credit bureaus in developing countries is nonexistent in the literature, creating a gap that this article attempts to fill.

\section{Information Sharing Arrangements}

How does a credit information system improve the functioning of a credit market? As shown formally in McIntosh and Wydick (2004), credit information systems first create a screening effect that improves risk assessment of loan applicants, thereby raising portfolio quality, which, in turn, reduces rates of arrears. Second, their very existence creates an incentive effect that may deter negligent borrower behavior as information about borrower behavior is shared among lenders. Some borrowers who are on the margin of misusing borrowed capital may be dissuaded from doing so if they sufficiently value future access to loans. In a competitive credit market, these efficiencies are passed on to borrowers in the form of a lower cost of capital. Improved informational flows thus enhance the efficiency and stability of the entire financial system. Yet because of the public good characteristics of credit information systems, the natural emergence of lower costs in the credit market is not always guaranteed.

Consequently, the breadth, depth, and general efficiency of credit information systems vary greatly among countries. Credit reporting, at some level, is a critical part of the financial system in most developed economies; in developing countries it is often much weaker if not altogether absent. This is because in a zero-information-sharing environment, repayment discipline in credit transactions typically happens via the oft-repeated transactions between a borrower and a single familiar lender in less developed countries (LDCs). However, because borrowers often lack the ability to send signals of their creditworthiness to the entire pool of potential lenders in LDCs, they are more susceptible to borrowing terms being dictated by a solitary lender with whom they have had a past borrowing relationship. In this way informational flows among lenders can paradoxically shift market power to borrowers.

The most basic level of information sharing among lenders involves sharing only negative information, such as borrower defaults and arrears. The simple creation of a public "blacklist" produces both screening and incentive effects, mitigating both adverse selection and moral hazard problems in the credit 
market. The existence of the blacklist helps lenders to avoid risky borrowers, and the fact that borrowers want to avoid being on the blacklist improves repayment incentives for borrowers who make it into the lending portfolio.

The most advanced information sharing arrangements, however, include positive borrower data in addition to the negative data. Positive data, or a "white list," may include the debtor's overall loan exposure and guarantees, data from past credit history other than defaults and arrears, and debtor characteristics such as employment, income, or line of business (Jappelli and Pagano 2000). The sharing of positive information allows for the debtor to create vital "reputation collateral," often in the form of a credit score that can provide valuable information to the credit market and signal a borrower's individual credit worthiness to a large pool of lenders. As demonstrated in McIntosh and Wydick (2005), the sharing of positive information helps to mitigate borrower overindebtedness, lower default rates in the overall credit market, and (in competition) reduce equilibrium interest rates.

\section{Empirical Work: Hypotheses and Data}

The subject for our empirical work is CREDIREF, a newly implemented, specialized credit bureau covering the microfinance sector of Guatemala. By the late 1990s, multiple loan taking by MFI clients had become so extensive that REDIMIF, an association of 19 MFIs, joined to establish CREDIREF, a centralized microfinance credit bureau, which has been functional since March 2002, in the central and eastern areas of Guatemala. Provoked by a desire to avoid an industry-wide repayment crisis similar to that experienced in Bolivia, CREDIREF's operations have grown steadily since its inception. By January of 2003, its database held information on upward of 120,000 borrowers. CREDIREF now collects data from six of the largest microfinance lenders in the country, while other MFIs are slowly being incorporated into the system.

Participation in CREDIREF includes a flat $\$ 70$ monthly membership fee plus an additional cost per consultation that decreases as the number of consultations rises. The first 100 consultations made per month each cost $\$ 1.60$, and prices decrease steadily to $\$ 0.67$ per consultation for over 6,400 consultations per month. Due to this fee structure and the potentially significant fixed costs of upgrading systems to provide digital reports, some small MFIs are unable to afford consultation fees. In other countries, credit bureaus have alleviated this problem somewhat with the solution of charging a membership fee that is scaled to the size of each participating institution. (For example, Bolivia's public credit registry charges participating financial institutions an annual fee equal to $1 / 1,000$ of their total assets [Campion 2001].)

CREDIREF collects and distributes a variety of data on microfinance bor- 
rowers, including positive and negative payment information. The data it collects on a borrower include the name, national identification number, size of current or most recent loan, whether the client is in default on any loan or payment, size and frequency of payments on current loan(s), and a 2-year history on the borrower's repayment record. The name of the lending institution is not included in a borrower's credit report in CREDIREF, an attempt to mitigate fears of client stealing among lenders. Additionally, CREDIREF does not provide a credit scoring service, leaving the individual institutions responsible for performing their own evaluations of potential borrowers.

We perform an impact analysis on CREDIREF's introduction, using data from the accounts of Génesis Empresarial ("Génesis"), a large-scale MFI and CREDIREF member that has 40 branch offices located throughout the country. The different branches began using the credit bureau at varying times. Panel data on the branch-level monthly arrears of Génesis provide a dynamic measurement of the credit bureau's impact as it was implemented office by office. To supplement these administrative data, during the summer of 2003, we carried out fieldwork, researching the implementation of CREDIREF in Guatemala. We surveyed 184 of Génesis' clients from six branch offices to learn what changes the introduction of a credit bureau had made in their borrowing behavior. The six branches visited were selected in order to have a wide range of implementation dates as branches entered into the credit bureau (see fig. 1 for a map of the branch offices of Génesis).

Génesis provides both positive and negative client information to CREDIREF and is consulting the database on an increasingly high share of loans disbursed. In June 2003, for example, Génesis branches made a total of 1,266 consultations to CREDIREF's database, of which 787 provided information on outside borrowing activity not otherwise observable to the lender. However, despite the growing importance of CREDIREF to Génesis operations, Génesis clientele had remained largely uneducated about the credit bureau's existence and operation. Of 184 surveyed clients from six branch offices from June to August of 2003, not one was aware of the credit bureau's creation. ${ }^{2}$ This finding is consistent with prior research showing that virtually no attention has been paid to educating consumers about credit reporting in Latin America (Miller 2003).

This dampens the effectiveness of the credit bureau, as knowledge of the existence of the credit information system is required to produce an "incentive

\footnotetext{
${ }^{2}$ Clients were asked both about the existence of a bureau in abstract and specifically about their knowledge of CREDIREF, and in both cases they were not aware that a bureau was sharing their information.
} 


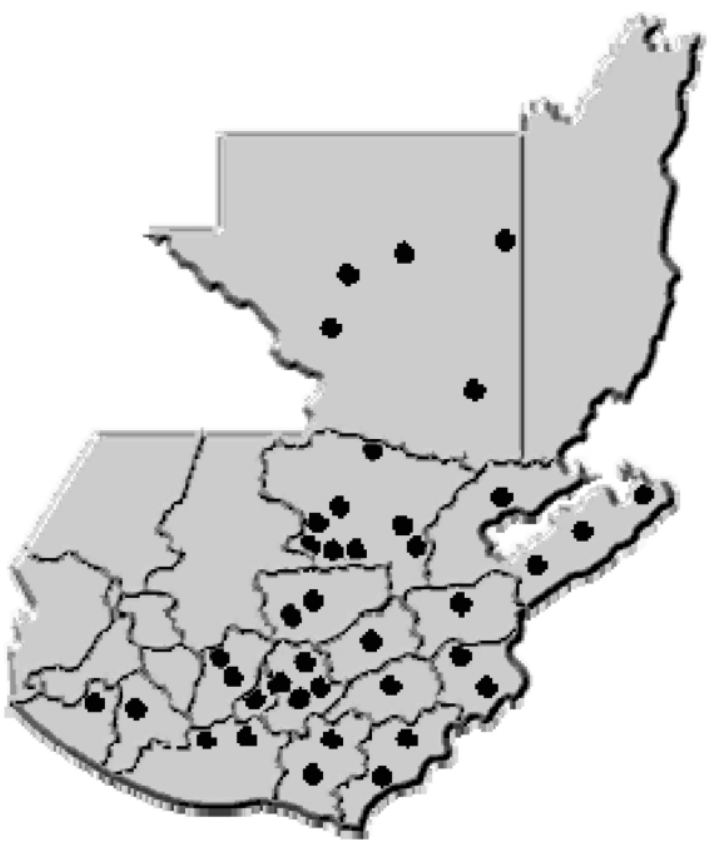

Figure 1. Map of Guatemala, featuring national department boundaries and the locations of the branches of Génesis Empresarial.

effect." If borrowers are unaware that their loan histories are being shared among various lenders and do not understand the implications of this, borrowing behavior will remain unchanged and the total effect of credit bureau implementation will consist solely of the screening effect.

As a result, our empirical work consists of a test for the pure screening effect of the credit bureau. We generate data to focus on the screening effect by writing the repayment performance of a loan onto the day on which it was received. This generates the possibility of a discontinuity in outcomes between those selected just before the use of a bureau and those selected just after.

The implementation of CREDIREF was technologically complex, requiring the branch offices of Génesis to improve hardware, software, and networking capabilities. For this reason, the rollout was staggered over the course of 18 months, taking place in nine different waves. Table 1 outlines the process.

We take the 34 administrative branch offices of Génesis that saw implementation of the bureau during the study period as the unit of analysis. Outcomes are calculated as monthly averages, and the 1,504 bureau/month observations form an unbalanced panel because some Génesis branches began operations after September 2000. We lack detailed, time-varying control data on the branches, and so, while we are able to conduct a variety of statistical 
TABLE 1

ORDER OF BRANCH INTRODUCTION TO CREDIT BUREAU

\begin{tabular}{|c|c|}
\hline Month of Introduction & Branch Name \\
\hline August 2001 & Metro Dos, Zona 4, Santa Lucia \\
\hline February 2002 & $\begin{array}{l}\text { Guatemala Personal, El Castano, Chimaltenango, Antigua, San } \\
\text { Juan Sacatepequez, Tecpan, El Castano }\end{array}$ \\
\hline April 2002 & Coban, Salama, San Pedro Carcha, San Cristobal, Tactic \\
\hline June 2002 & Esquintla, Suchitepequez, Retalhuleu, Chiquimulilla, Guastatoya \\
\hline August 2002 & Jutiapa, Jalapa, Cuilapa \\
\hline September 2002 & Zacapa, Chiquimula, Esquipulas \\
\hline October 2002 & Peten, Poptun, Melchor de Mencos \\
\hline November 2002 & Izabal, Raxruha, Sayaxche, Morales, Los Amates, El Estor \\
\hline January 2003 & La Libertad \\
\hline Not included & Pozo Maya \\
\hline
\end{tabular}

Note. Prior to March 2002, dates signify when offices began consulting INFORNET, a complementary risk-management database to CREDIREF. INFORNET closed operations in May of 2003, and now CREDIREF operates alone. INFORNET provided only negative information on press publications, court rulings, any public record information, and credit card and bank account information. Treatment is considered to be the same whether the date of introduction is to CREDIREF or INFORNET for each branch.

tests, we must in general assume that time-varying, branch-specific determinants of repayment are orthogonal to the structure of the rollout of the bureau.

One possibility that would affect the accuracy of our estimations would be if the installation of the new hardware and software needed to run the new system affected repayment rates in other ways than the influence of the credit information system itself. We view this as unlikely. Borrower repayment rates are influenced most directly by the screening of clients, the productivity and behavior of borrowers, shocks received by borrowers, and the fieldwork practices of loan officers. Since the introduction of the system left other functions of the MFI unchanged, except for the added screening mechanism in the loan review process, it is unlikely that the introduction of new computers, servers, and software needed to operate the system had any direct effect on loan repayment by borrowers.

As a measure of loan delinquency, we feature the percentage of loans in a branch that were late as of the last payment made. This is a very sensitive measure of repayment that picks up roughly twice the number of problems as the technical definition of default used by the institution (which includes only loans beyond a month overdue). We feature this measure because it varies more than technical default and also because it can be calculated directly from the accounts of the institution. The data otherwise available from the institution on technical default in a month are the stock of bad loans, whose month-to-month changes are a composite of forgiveness and new defaults and therefore difficult to interpret. 


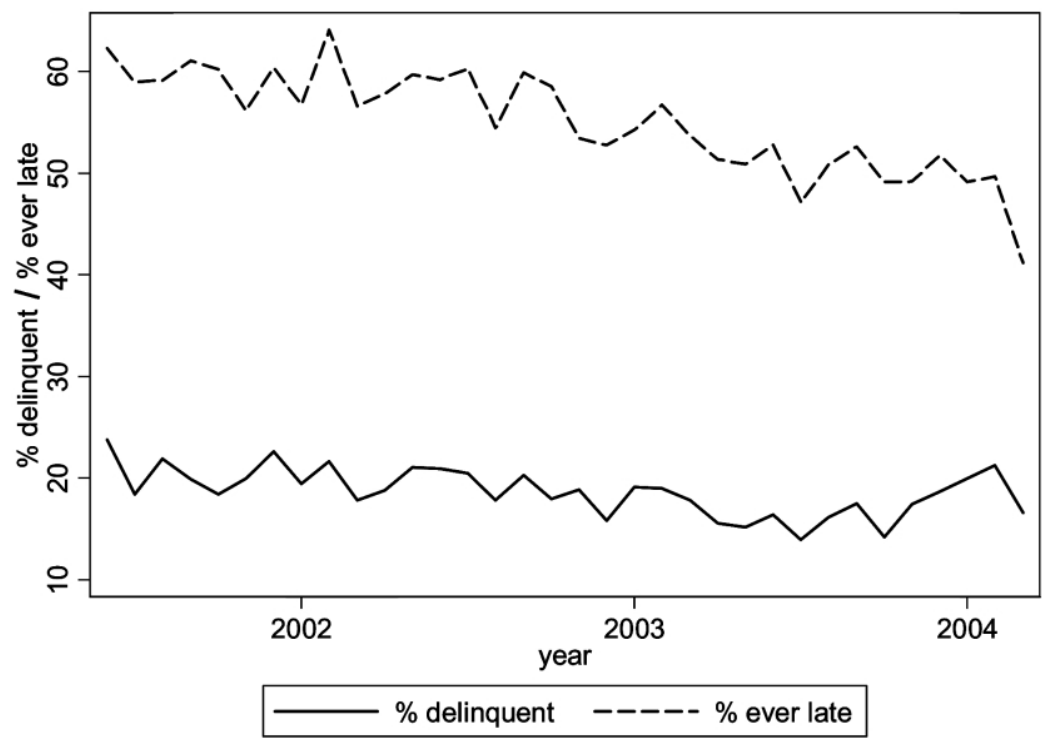

Figure 2. Change in delinquency over time

We also examine three additional outcomes: the percentage of loans in a branch/month on which a payment is ever late, the average number of late payments per loan in a branch/month, and the average number of months late for loans issued in a branch/month that become delinquent, which measures the severity of repayment problems. Because some branch/months have no delinquency, this variable is missing for almost half the observations.

\section{Empirical Results}

As a first take on the data, figure 2 plots the percentage of loans ever late and the percent delinquent over time. There is a clear visual improvement in the "percent ever late," while any potential decrease in delinquency appears more modest. The nature of the quasi-experiment used for identification can be more clearly seen in figure 3, which lines up the staggered entry of the branches into CREDIREF so that zero indicates the month in which every branch entered. Now there appears to be a clearer impact on both outcomes. "Percent ever late" jumps discontinuously and appears to have a kink in the slope, and while the effect on delinquency is less clear, it does appear to have fallen fairly discontinuously from a mean of $20 \%$ to a mean of $18 \%$ or so.

In order to formalize the analysis of a discontinuous treatment effect, we pursue an iterative set of $t$-tests to examine how many months must be considered before a paired $t$-test of pre- and post-treatment means within branches becomes significant. We begin by comparing 1 month before treat- 


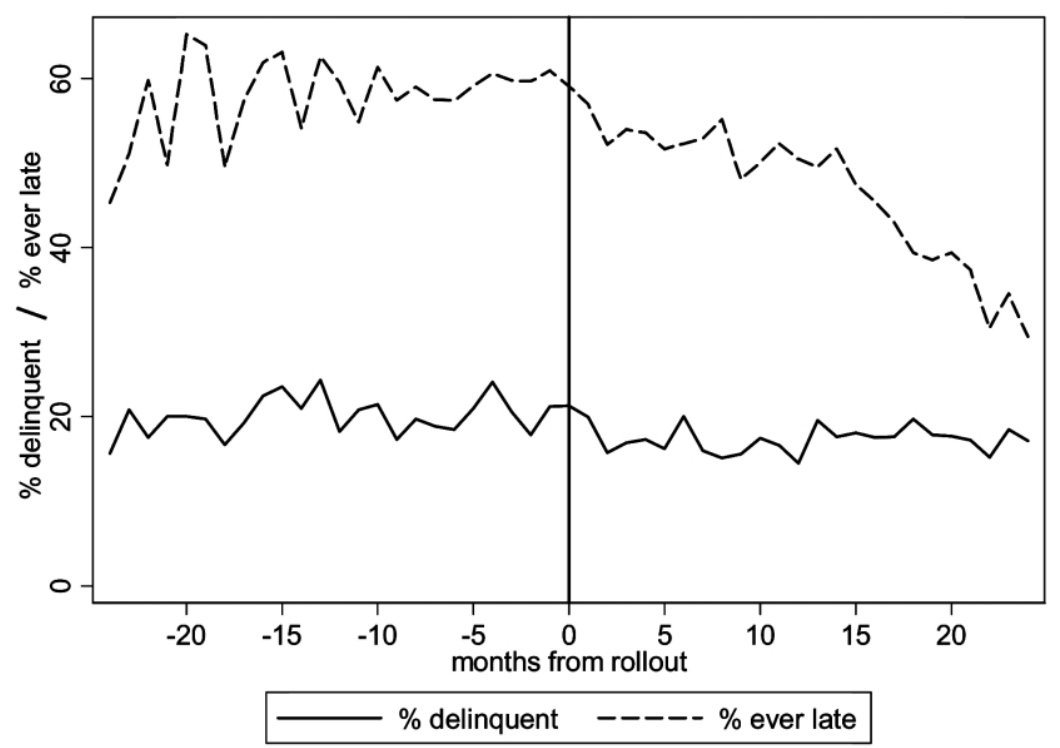

Figure 3. Change in delinquency around rollout

ment to 1 month after, then the mean across the 2 months before treatment to the mean 2 months after, and so on. Figures 4 and 5 plot the results of this exercise. The effect on delinquency appears to be continuous; the first month is very close to zero and insignificant, while by the fourth month we see significance of a difference of close to 3 percentage points. The impact on percent ever late, however, does show discontinuity; within the first month a difference of greater than 4 percentage points exists. While, on average, over 2 months is required in order to smooth outcomes and reduce variance sufficiently to generate significance, the difference is essentially unchanged as the window expands.

A more fine-grained set of $t$-tests is presented in table 2 . Here we test branch by branch for pairwise differences in the pre-treatment and posttreatment levels of delinquency, using all time periods available. The results are again quite clear; of the 13 branches with significant changes at the $90 \%$ level, only one of those saw higher post-treatment delinquency; in the remainder, it decreased. The branch with increasing delinquency was already an outlier in terms of levels; moreover, this branch, Zona 4, is located in a part of the capital that saw spiraling drug-related violence during the study period.

Comparing $t$-tests provides an intuitive way of approaching the question of impact in a quasi-experiment and has the additional advantage that, in cases of autocorrelated outcomes, such before-after mean comparisons remain consistent (Bertrand, Duflo, and Mullainathan 2003). Once we are including 


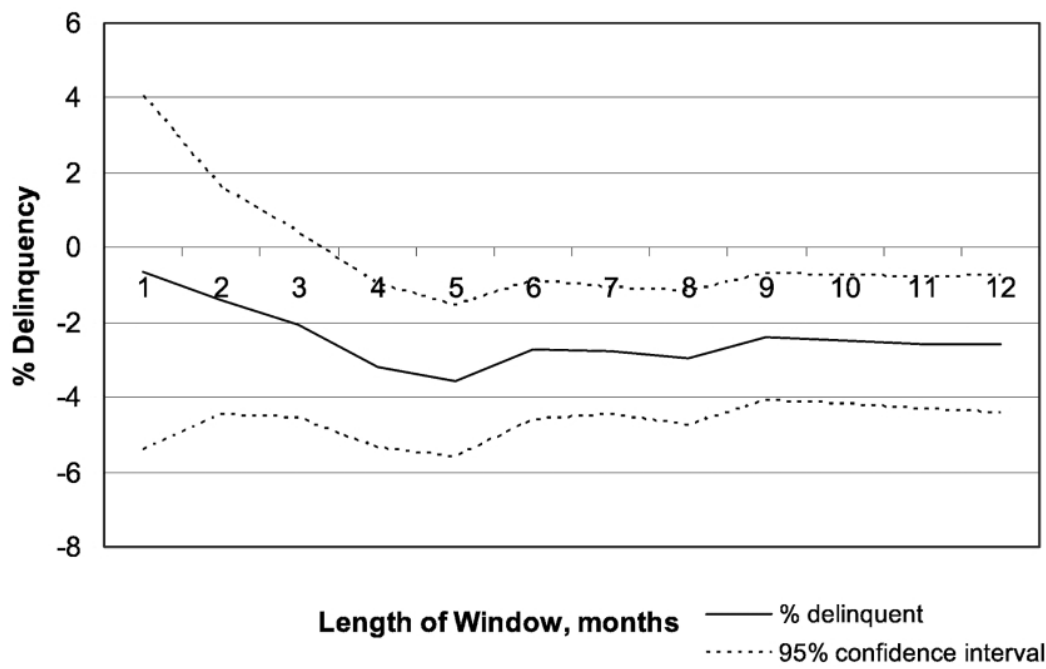

Figure 4. T-tests of bureau impact, \% delinquency

a longer time period in our analysis, however, it becomes necessary to introduce controls for time in order to avoid spurious treatment effects.

Table 3 presents a set of analyses using month- and branch-level fixed effects,

$$
\text { Outcome }_{i t}=\alpha_{i}+\gamma_{t}+\delta C B_{i t}+\mu_{i t} \text {, }
$$

where $\alpha_{i}$ is the branch-specific fixed effect, $\gamma_{t}$ is a month dummy, $C B_{i t}$ is the treatment indicator, and $\mu_{i t}$ is an error term.

Two treatment indicators are used. The first, a dummy equal to zero before the bureau was rolled out to a branch and one after, indicates the presence of

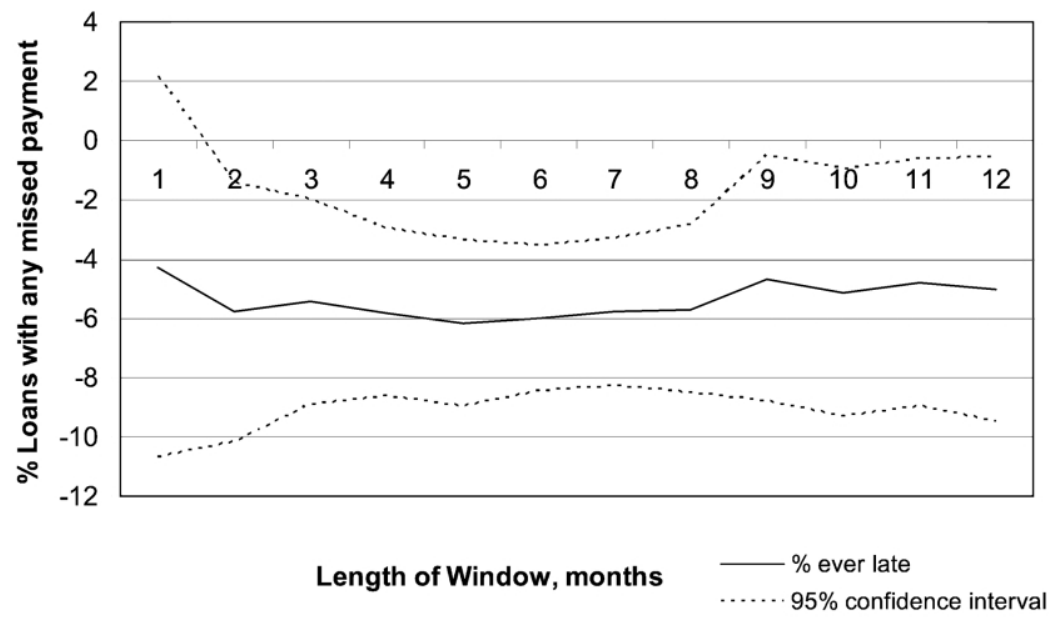

Figure 5. T-tests of bureau impact, \% loans ever late 
TABLE 2

SUMMARY STATISTICS OF DELINOUENCY ACROSS BRANCHES

\begin{tabular}{|c|c|c|c|}
\hline Branch & $\begin{array}{l}\text { Pre-treatment } \\
\text { Arrears }\end{array}$ & $\begin{array}{c}\text { Post-treatment } \\
\text { Arrears }\end{array}$ & Change \\
\hline 3. Metro Dos, Zona 4 & 2.65 & 5.25 & $2.60 * \star \star$ \\
\hline 4. Metro Tres, El Castano & 22.16 & 25.98 & 3.82 \\
\hline 5. Chimaltenango & 11.12 & 12.65 & 1.53 \\
\hline 6. Antigua & 16.00 & 18.09 & 2.09 \\
\hline 7. Esquintla & 24.05 & 20.41 & $-3.64^{\star}$ \\
\hline 8. Suchitepequez & 12.85 & 11.80 & -1.05 \\
\hline 9. Retalhuleu & 17.71 & 16.15 & -1.56 \\
\hline 10. Izabal & 23.91 & 16.99 & $-6.92^{\star \star}$ \\
\hline 11. Zacapa & 19.96 & 11.67 & 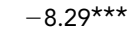 \\
\hline 13. Chiquimula & 19.46 & 22.72 & 3.25 \\
\hline 14. Coban & 32.96 & 29.41 & -3.55 \\
\hline 16. San Juan Sacatepequez & 18.98 & 19.22 & .24 \\
\hline 17. Jutiapa & 21.09 & 20.20 & -.89 \\
\hline 18. Jalapa & 23.36 & 17.49 & -5.86 \\
\hline 19. Peten & 15.36 & 14.82 & -.54 \\
\hline 21. Cuilapa & 21.48 & 15.39 & $-6.09 \star \star$ \\
\hline 22. Esquipulas & 17.44 & 18.70 & 1.26 \\
\hline 23. Chiquimulilla & 16.36 & 14.36 & -2.00 \\
\hline 24. Santa Lucia & 16.44 & 18.35 & 1.92 \\
\hline 25. Salama & 16.51 & 10.16 & $-6.35^{\star \star \star}$ \\
\hline 26. Guastatoya & 31.60 & 24.44 & $-7.16^{\star \star}$ \\
\hline 28. San Pedro Carcha & 23.54 & 22.35 & -1.20 \\
\hline 29. Rabinal & 32.34 & 16.52 & $-15.82^{\star \star \star}$ \\
\hline 31. Raxruha & 19.56 & 10.17 & $-9.40 \star \star$ \\
\hline 32. Poptun & 15.84 & 9.98 & $-5.86^{\star \star \star}$ \\
\hline 33. Sayaxche & 16.81 & 11.52 & -5.30 \\
\hline 34. La Libertad & 15.10 & 16.82 & 1.71 \\
\hline 35. Morales & 24.74 & 18.40 & $-6.34^{\star}$ \\
\hline 36. Los Amates & 22.35 & 15.02 & $-7.33^{\star}$ \\
\hline 37. San Cristobal & 24.54 & 21.51 & -3.03 \\
\hline 38. Tactic & 35.04 & 23.16 & -11.88 \\
\hline 39. El Estor & 37.34 & 16.03 & $-21.31^{\star \star \star}$ \\
\hline 40. Melchor de Mencos & 18.01 & 11.37 & -6.64 \\
\hline 41. El Castano & 8.69 & 8.73 & .03 \\
\hline Overall & 20.09 & 17.12 & $-2.97^{\star \star \star}$ \\
\hline
\end{tabular}

* Significant at the $10 \%$ level.

$\star \star$ Significant at the $5 \%$ level.

$\star \star \star$ Significant at the $1 \%$ level.

the bureau, while a variable measuring the number of checks performed in the bureau each month measures the intensity of use. The strongest impact seen here is a huge decrease in the average number of missed payments; this outcome responds strongly to both presence and intensity of use of the bureau. The use of the bureau decreases the percentage of loans on which any payments are missed by 3.3 percentage points and the number of missed payments by 1.3. It is interesting that the impact of the bureau on delinquency, at 1.1 percentage points, is both smaller than that seen in the $t$-tests and insignificant. Regressions performed using less robust error structures resulted in an outcome 
TABLE 3

FIXED-EFFECT REGRESSIONS WITH MONTH DUMMIES

\begin{tabular}{|c|c|c|c|c|c|c|c|}
\hline \multirow[b]{3}{*}{ Outcome Variable } & \multicolumn{6}{|c|}{ Treatment Variable } & \multirow[b]{3}{*}{$N$} \\
\hline & \multicolumn{3}{|c|}{ Dummy for Use of Bureau } & \multicolumn{3}{|c|}{ Number of Checks/Month } & \\
\hline & Coefficient & SE & $P>|t|$ & Coefficient & SE & $P>|t|$ & \\
\hline$\%$ delinquent & -1.122 & .860 & .201 & .0005 & .006 & .933 & 1,504 \\
\hline$\%$ ever late & $-3.326^{\star \star}$ & 1.490 & .032 & -.0150 & .010 & .131 & 1,504 \\
\hline Number of late payments & $-1.311^{\star \star \star}$ & .401 & .002 & $-.0084^{\star \star \star}$ & .002 & .000 & 1,504 \\
\hline Months, if delinquent & -.222 & .488 & .652 & -.0049 & .003 & .121 & 824 \\
\hline
\end{tabular}

Note. All regressions are weighted by the size of the loan portfolio and use robust clustered standard errors.

$\star \star$ Significant at the $5 \%$ level.

$\star \star \star$ Significant at the $1 \%$ level.

that was just significant at the .05 level, but the presence of autocorrelation within bureaus sufficiently increases the standard error as to render a $p$-value of only 0.20 . The number of months by which late payments were late shows no change.

If, instead of controlling for time using month dummies, we use a linear time trend, we can check not only for the mean effect of the bureau but also for the presence of a kink in the rate of change of outcomes after the introduction of the bureau:

$$
\text { Outcome }_{i t}=\alpha_{i}+\beta t+\delta C B_{i t}+\rho\left(C B_{i t} \times t\right)+\mu_{i t} .
$$

Table 4 presents the results of estimations performed using fixed effects at the branch level and errors robust to clustering within branches. The result for "delinquency" here is very much in line with the visual impression given by figure 2, a level drop of about $2 \%$ with little change in slope. The results for "percent ever late" coincide with figure 3; this outcome, as well as the number of late payments and the months late variable, show a strongly decreased trend after the implementation of the bureau but no level effect. The implication is that, while the bureau had a fixed small effect on delinquency, the other indicators saw an improvement that was increasing in experience with the bureau. These results would be consistent with the need to learn how to use the bureau to maximum advantage.

An additional question is whether the magnitude of the treatment effect is related to the levels of the outcome variables when the bureau was introduced. By taking the last outcome variable observed before the use of the bureau and interacting this (demeaned) outcome with the treatment dummy, we can answer this question. We continue to use branch- and month-level 
TABLE 4

FIXED-EFFECT REGRESSIONS WITH BEFORE/AFTER TRENDS

\begin{tabular}{|c|c|c|c|c|}
\hline Outcome Variable & Coefficient & SE & $P>|t|$ & $\begin{array}{l}\text { Number of } \\
\text { Observations }\end{array}$ \\
\hline$\%$ delinquent & & & & 1,504 \\
\hline Time trend & .019 & .057 & .740 & \\
\hline Bureau dummy & $-1.924^{\star \star}$ & .841 & .028 & \\
\hline Trend after bureau & $-.117^{\star}$ & .068 & .094 & \\
\hline$\%$ ever late & & & & 1,504 \\
\hline Time trend & $-.312^{\star}$ & .163 & .063 & \\
\hline Bureau dummy & .379 & 3.065 & .902 & \\
\hline Trend after bureau & $-.799 * \star \star$ & .230 & .001 & \\
\hline Number of late payments & & & & 1,504 \\
\hline Time trend & $-.069^{\star}$ & .039 & .082 & \\
\hline Bureau dummy & -.253 & .664 & .705 & \\
\hline Trend after bureau & $-.159 \star \star \star$ & .054 & .006 & \\
\hline Months, if delinquent & & & & 824 \\
\hline Time trend & $-.190 \star \star \star$ & .031 & .000 & \\
\hline Bureau dummy & -.145 & .506 & .777 & \\
\hline Trend after bureau & $-.070^{\star \star}$ & .032 & .036 & \\
\hline
\end{tabular}

Note. All regressions are weighted by the size of the loan portfolio and use robust clustered standard errors.

* Significant at the $10 \%$ level.

** Significant at the $5 \%$ level.

$\star \star \star$ Significant at the $1 \%$ level.

fixed effects and therefore do not need to include the uninteracted pre-treatment outcome because it is subsumed in the branch-level fixed effect:

$$
\text { Outcome }_{i t}=\alpha_{i}+\gamma_{t}+\delta C B_{i t}+\rho\left(C \times B_{i t} \text { Outcome }_{0 i}\right)+\mu_{i t} .
$$

The results of this exercise are presented in table 5. Again, we observe that the use of month-level fixed effects eliminates the significance of the bureau on delinquency, but all three of the other outcomes display strong negative interaction effects. The implication is that the higher the level of the outcome was prior to the use of the bureau, the larger the fall in outcomes once the bureau was introduced. Hence, the bureau is most effective at reducing late payments and months in delinquency where these problems were worse before implementation.

\section{A. Robustness Checks}

The value of the quasi-experiment generated by the staggered rollout of CREDIREF for measurement purposes depends on the timing of that rollout. If, for example, the sequencing of the rollout is correlated with expected rates of change in the outcomes, then a bias will be introduced. Equivalently, if branches in crisis at any moment in time were given the bureau and the outcomes display a tendency toward mean reversion, then our impact estimate 
TABLE 5

INTERACTIONS WITH OUTCOMES BEFORE ROLLOUT OF BUREAU

\begin{tabular}{|c|c|c|c|c|}
\hline Outcome Variable & Coefficient & SE & $P>|t|$ & $\begin{array}{l}\text { Number of } \\
\text { Observations }\end{array}$ \\
\hline \multicolumn{5}{|l|}{$\%$ delinquent: } \\
\hline Credit bureau dummy & -1.334 & .885 & .141 & \multirow[t]{2}{*}{1,440} \\
\hline Interaction with pre-bureau level & -.087 & .083 & .306 & \\
\hline \multicolumn{5}{|l|}{$\%$ ever late: } \\
\hline Credit bureau dummy & $-4.585^{\star \star \star}$ & 1.401 & .003 & \multirow[t]{2}{*}{1,440} \\
\hline Interaction with pre-bureau level & $-.313^{\star \star \star}$ & .069 & .000 & \\
\hline \multicolumn{5}{|l|}{ Number of late payments: } \\
\hline Credit bureau dummy & $-1.429^{\star \star \star}$ & .324 & .000 & \multirow[t]{2}{*}{1,440} \\
\hline Interaction with pre-bureau level & $-.444^{\star \star}$ & .036 & .000 & \\
\hline \multicolumn{5}{|l|}{ Months, if delinquent } \\
\hline Credit bureau dummy & -.219 & .342 & .526 & \multirow[t]{2}{*}{806} \\
\hline Interaction with pre-bureau level & $-.451^{\star \star \star}$ & .050 & .000 & \\
\hline
\end{tabular}

Note. All regressions are weighted by the size of the loan portfolio and use robust clustered standard errors.

** Significant at the $5 \%$ level.

$\star \star \star$ Significant at the $1 \%$ level.

would be biased downward. If true, mean reversion would influence the observed interaction effects in table 5.

In order to test for endogeneity in the sequencing of the rollout, we perform a number of comparisons of pre-treatment averages across the month in which the branch first began to use the bureau. This analysis is performed both in levels, which test for whether the sequencing was endogenous to the outcomes, and in first differences, which test for endogeneity in the rate of change. Time of rollout is measured using a variable that begins at 1 in January 2000 and increases by 1 for every month thereafter. Table 6 presents the results of OLS regressions of these outcomes on the rollout time as well as Spearman rank correlation coefficients for whether there is correlation between the rank of the outcomes and the rank in which the bureau was received. The first differences show no relationship to the sequencing of rollout, although the level of delinquency is nearly significant at the .10 level in the Spearman test. Figure

TABLE 6

TESTS FOR ENDOGENEITY OF ROLLOUT

\begin{tabular}{|c|c|c|c|}
\hline & \multicolumn{2}{|c|}{ Ordinary Least Squares } & \multirow{2}{*}{$\frac{\text { Spearman }}{P>|t|}$} \\
\hline & Coefficient & $P>|t|$ & \\
\hline \multicolumn{4}{|l|}{ Level of outcome: } \\
\hline$\%$ delinquent & -2.239 & .27 & .11 \\
\hline$\%$ ever late & -2.359 & .52 & .23 \\
\hline \multicolumn{4}{|l|}{ First differences: } \\
\hline$\%$ delinquent & -.118 & .61 & .45 \\
\hline$\%$ ever late & -.274 & .42 & .50 \\
\hline
\end{tabular}

Note. The independent variable is the month in which the bureau was received by the branch (January $2000=1$ with increase of 1 for each subsequent month). 


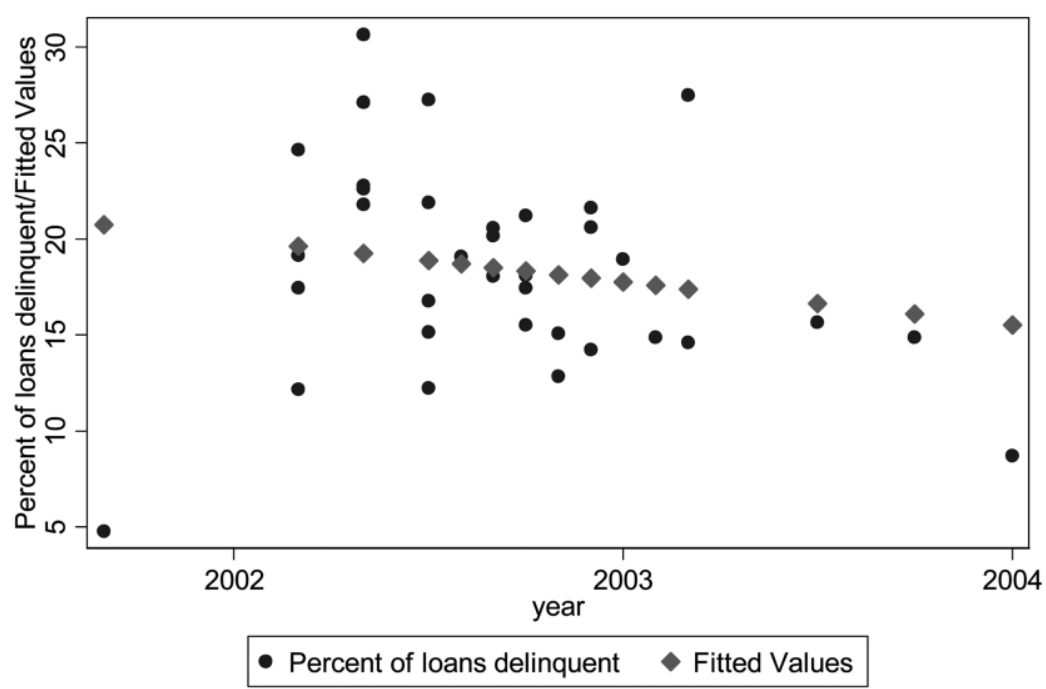

Figure 6. Delinquency by month bureau introduced

6 plots this relationship as well as the fitted values from the OLS regression. We see that indeed there is a slight downward trend (meaning that those with higher initial delinquency got the bureau first) but that the problem is not severe.

Since rates of change are not correlated with the rollout, the primary concern raised by this analysis is that, in the presence of mean reversion, some bias may exist due to correlation between the order of the rollout and initial branch delinquency. To test for mean reversion, table 7 shows the results of similar OLS and Spearman tests for whether a correlation exists between the first observation of each outcome in the data and the subsequent trend in that outcome prior to the introduction of the bureau. There is no evidence here for mean reversion, an impression which is reinforced by figure 7, which plots initial levels against subsequent changes, along with the fitted OLS values. The absence of mean reversion in the data is reassuring not only in confirming the basic structure of this quasi-experiment but also in aiding our ability to draw causal inference from the results of the interactions presented in table 5.

TABLE 7

TEST FOR MEAN REVERSION

\begin{tabular}{lcccc}
\hline \multirow{2}{*}{$\begin{array}{l}\text { Average Monthly Change } \\
\text { prior to Bureau }\end{array}$} & \multicolumn{2}{c}{ Ordinary Least Squares } & & Spearman \\
\cline { 2 - 2 } \% delinquent & Coefficient & $P>|t|$ & & $P>|t|$ \\
\hline \% ever late & .005 & .74 & .74 \\
\hline
\end{tabular}

Note. The individual variable is the initial level of outcome. 


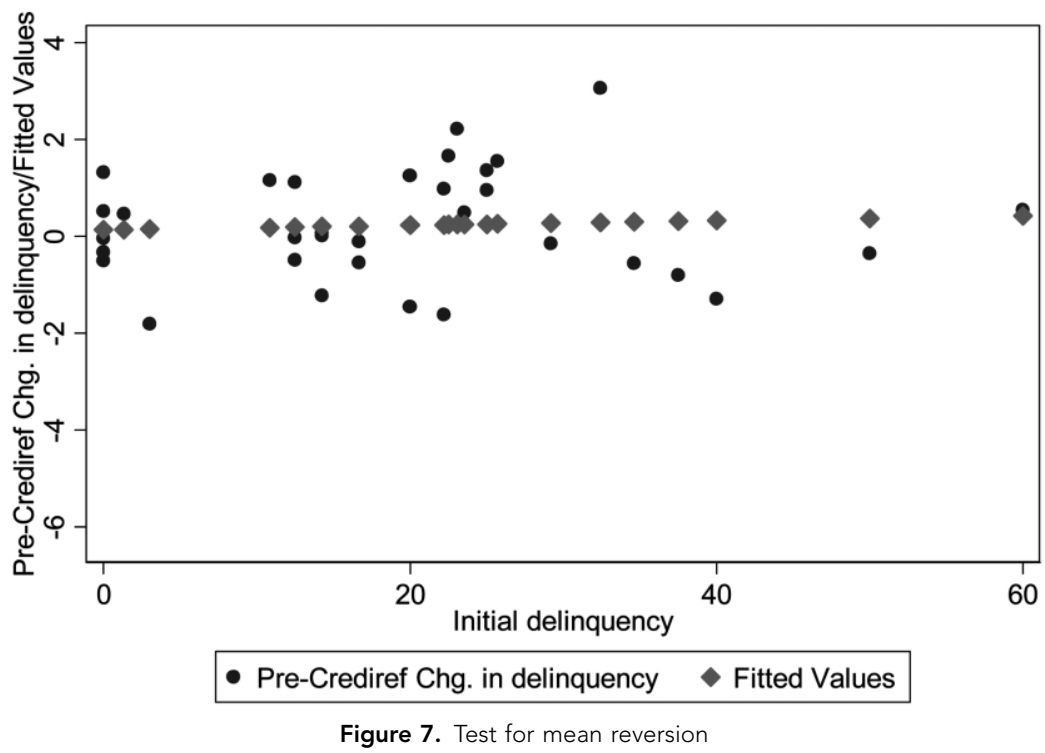

\section{B. Assessing Costs and Benefits of a Credit Information System}

Given that our results indicate significant impacts on portfolio quality, we investigate whether the discounted benefits of a system such as CREDIREF exceed the discounted costs of its implementation. We address several pertinent questions: Are the benefits to an individual MFI of a credit information system, as we measure them, worth the cost of its implementation? Based on our estimates, what is the probability that the net present value of such a system to a credit institution is greater than zero? And finally, what are the welfare implications of such a system being implemented in a competitive market?

According to administrators, the costs to Génesis were principally composed of installation of hardware, new telephone lines, and additional furniture to each of their 40 branch offices needed to support the system. (Here we convert all figures from Guatemalan quetzales to U.S. dollars.) For each branch office, new hardware amounted to approximately US $\$ 8,000$, new telephone lines to US $\$ 450$, and furniture to approximately US $\$ 800$. Total software costs to the institution were US $\$ 1,280$, making the total costs of installation to Génesis equal to US $\$ 371,280$. (These assets were expected to need replacement or updating on average every 3 years; we therefore use this 3 -year time horizon in our analysis.) CREDIREF is operated by an outside entity, Banca Red, to whom Génesis pays the fixed monthly fee of US $\$ 70$ plus an average of US $\$ 1.14$ for each consultation to the database plus a US $\$ 0.26$ telephone charge. On 
average administrators report about 2,000 consultations per month, making the variable costs of consultations equal to US $\$ 34,400$ per year.

At the end of 2004, the total value of Génesis' portfolio of microloans was US $\$ 25,441,273$. We have several estimates of the effect of the information system in our research. The overall average drop in observed branch-level preand post-treatment arrears was shown to be 2.97 percentage points. Our fixed effects estimation using month dummies yields an (insignificant) drop of 1.12 percentage points, while our estimation controlling for (before and after) trends shows a (significant) drop of 1.92 percentage points. Given its significance and the importance of controlling for trends, we use the latter in our analysis.

Not all loans in 30-day arrears are written off and represent a loss to the institution. Consistent with the observed pattern in Génesis, we will thus assume that approximately half of this amount can be recovered at little or no cost to the institution and/or is compensated for by interest penalties, while the other half is either written off or is recovered only at a cost equal to the debt itself. We will refer to this figure as the default rate. This would suggest that CREDIREF is able to save Génesis US $\$ 244,745$ per year in allowances for bad debt. Assuming a discount rate of $10 \%$ (a rough approximation of the constantly varying weighted cost of funds to the MFI through a combination of commercial borrowing and below-market loans), this yields a net present value of the CREDIREF information system over 3 years to Génesis of US $\$ 185,570$, or US $\$ 61,857$ per year. The net present value is fairly insensitive to the interest rate; implementation of the system carries a colossal internal rate of return of $96.5 \%$. It is, however, sensitive to the reduction in default rate yielded through implementation of the system. For the net present value of implementation of the system to remain positive, the reduction in 30-day arrears must exceed 1.34 percentage points. A standard error on the estimate of 0.841 implies that implementation carries a projected positive net present value at slightly more than a $75 \%$ confidence level, assuming the level of 30-day arrears reduction is the only stochastic element in system implementation.

The reduction in arrears from the system should also reduce the interest rate offered by the institution if microfinance markets are competitive and borrower information is widely accessible. If economic profits per dollar loaned are zero, then $(1-d)(1+r)-(1+c+F)=0$, where $d$ is the default rate, $r$ is the interest rate, $c$ is the cost of borrowing, and $F$ is the administration cost per dollar on a new loan of average size. Using December 2003 figures for Génesis, we have (approximately) that $d=0.04, r=0.36$, and $c=0.10$. Solving for $F$, we find that, in equilibrium, $F$ would be equal to about 0.15 . If we solve 
for the institutional interest rate and differentiate with respect to the default rate, we obtain

$$
\frac{\partial r}{\partial d}=\frac{1+c+F}{(1-d)^{2}} \approx 1.35 .
$$

Thus, for our estimated system impact of a 1.92 percentage-point decline in the default rate, we would estimate a decline in a competitive interest rate of approximately 2.59 points.

\section{Conclusions and Implications for Policy}

Credit information systems help build an efficient financial system by promoting transparency in lending. They are effective tools toward mitigation of adverse selection and moral hazard in credit markets, and they have been found to lower overall default and interest rates and improve the pool of borrowers in formal credit markets. A survey of credit information systems worldwide reveals that developing countries are quickly realizing the importance and usefulness of information sharing and that there has been burgeoning growth in the implementation of such systems in the last decade, particularly in Latin America and Asia. The explosion in microfinance activity in developing countries has contributed to this need. We presented evidence that the beneficial effects of credit information systems are to be found when bureaus are utilized in the microfinance sector. We believe that increased competition in many regions among microfinance lenders has made credit bureaus a necessary step toward financial sector stability.

CREDIREF has had a strong impact in terms of decreasing the prevalence of missed payments in Génesis. The introduction saw a discontinuous drop in the percentage of clients missing a payment, and the effect gathered strength over the course of the time the bureau was used. The fall in the percentage of clients missing payments is 4.5 percentage points plus an additional .3 percentage points per month the system is used. Impact on the number of late payments is similarly dramatic. Evidence for the impact of CREDIREF on delinquency is more mixed; using $t$-tests or a regression with fixed effects and a linear time control we find a significant reduction of from 1 to 3 percentage points as a result of the use of the system, where in some estimations the effect becomes insignificant. The implication is that there was a nonlinear fall in delinquency after the bureau that was common to all of the branches; how we ascribe causality for this drop determines whether or not the causal effect of the bureau is significant on delinquency. The number of months by which late payments are late shows no immediate improvement, but there exists a gradual improvement over time, that is, 2 days shorter delinquency period for each month that CREDIREF 
is used. There is evidence that CREDIREF has the strongest impact in environments where the repayment problems were worst to begin with.

How are we to interpret this strong fall in missed intermediate payments without a correspondingly strong impact on eventual delinquency? One answer would relate to the additional kinds of information to which credit officers gain access through the use of the system. If we assume that borrowers who have had a given type of repayment problem with one lender will continue to have the same kinds of problems with other lenders, one possible explanation presents itself. Applicants for loans already go through extensive screening procedures that include interviews with neighbors and business associates. It may be that past default is a sufficiently dramatic and public event that preexisting screening mechanisms were sufficient to catch such applicants. Missing payments, however, is likely to be the private information of the lender and borrower, and so it may be this more nuanced understanding of past performance that is the unique contribution of CREDIREF to the information set possessed by credit officers. Seen from this perspective, the fact that the impact on intermediate payments is much stronger than on eventual default is reasonable.

An extension of this work is the importance of the incentive effect formally derived in McIntosh and Wydick (2004) in realizing the full benefit of a positive information sharing network. Our finding during fieldwork that not one surveyed client in Guatemala had been aware of the credit bureau's existence was disturbing. With borrowers unaware of their role in an information sharing arrangement, incentive effects cannot be realized. This causes the full potential for credit bureaus to remain unrealized in improving credit market performance. Given that the estimates of impact given here consist solely of the screening effects, they should be viewed as a lower bound on the full impact of the introduction of a robust credit reporting system whose rules are well understood by borrowers. Client outreach and education in this regard may have efficiency benefits in addition to being equitable.

As credit markets continue to expand and overlap, the functioning of credit bureaus takes on greater importance. While the microfinance revolution provided many with access to credit for the first time, its ability to continue to do so depends upon sustainability of the market. The potential for credit bureaus is immense in this area.

\section{References}

Abreu, Saúl. 2001. "Case Studies of Selected Credit Bureaus in Several Latin American Countries." Working paper, GTZ Department 41, Financial Systems Development and Banking Services, Deutsche Gessellschaft für Technische Zusammenarbeit (GTZ), Eschborn (October). 
Akerlof, George. 1970. “The Market for 'Lemons.'” Quarterly Journal of Economics 84: 488-500.

Bertrand, Marianne, Esther Duflo, and Sendhil Mullainathan. 2003. "How Much Should We Trust Difference-in-Differences Estimates?” Working paper, Department of Economics, Massachusetts Institute of Technology.

Campion, Anita. 2001. "Client Information-Sharing in Bolivia." Journal of Microfinance 3:45-64.

Campion, Anita, and Liza Valenzuela. 2001. "Credit Bureaus: A Necessity for Microfinance?” Working paper, Microenterprise Best Practices Project, USAID, Bethesda, MD.

$\rightarrow$ Hoff, Karla, and Joseph E. Stiglitz. 1998. "Moneylenders and Bankers: Price-Increasing Subsidies in a Monopolistically Competitive Market." Journal of Development Economics 55:485-518.

$\rightarrow$ Jappelli, Tullio, and Marco Pagano. 1993. "Information Sharing in Credit Markets." Journal of Finance 48 (December): 1693-1718.

. 2000. "Information Sharing in Credit Markets: A Survey." CSEF Working Paper no. 36, Department of Economics, Centre for Studies in Economics and Finance, University of Salerno. http://www.iue.it/FinConsEU/ResearchActivities/ EconomicsofConsumer CreditMay2003/Papers/Jappelli.pdf.

$\rightarrow$. 2002. "Information Sharing, Lending and Defaults: Cross-Country Evidence." Journal of Banking and Finance 26 (October): 2017-45.

Lenaghan, Tom. 2001. "Microfinance and the Market for Credit Information in El Salvador.” Microenterprises Best Practices, Development Alternatives, Inc., Bethesda, MD.

Matin, Imran. 2001. "Dimensions and Dynamics of MFI Competition in Bangladesh.” Working paper, CGAP Note Book 1, Consultative Group to Assist the Poorest, Washington, DC.

McIntosh, Craig, and Bruce Wydick. 2004. "A Decomposition of Incentive and Screening Effects in Credit Market Information Systems." Working paper, Department of Economics, University of California, San Diego, School of International Relations and Pacific Studies, and University of San Francisco.

$\rightarrow \longrightarrow$. 2005. "Competition and Microfinance." Journal of Development Economics 78 (December): 271-98.

Miller, Margaret J. 2003. "Credit Reporting Systems around the Globe: The State of the Art in Public Credit Registries and Private Credit Reporting Firms." In Credit Reporting Systems and the International Economy, ed. Margaret J. Miller. Cambridge, MA: MIT Press.

$\rightarrow$ Padilla, Jorge A., and Marco Pagano. 1997. "Endogenous Communication among Lenders and Entrepreneurial Incentives." Review of Financial Studies 10 (Spring): 205-36.

$\rightarrow$. 2000. "Sharing Default Information as a Borrower Discipline Device." European Economic Review 44 (December): 1951-80.

$\rightarrow$ Stiglitz, Joseph E., and Andrew Weiss. 1981. "Credit Rationing in Markets with Imperfect Information.” American Economic Review 71 (June): 393-410.

$\rightarrow$ Vercammen, James A. 1995. "Credit Bureau Policy and Sustainable Reputation Effects in Credit Markets.” Economica 62 (November): 461-78. 